\title{
PENINGKATAN KEMAMPUAN GURU MELALUI PELATIHAN KEWIRAUSAHAAN DAN MOTIVASI MODEL PEMBELAJARAN DARING
}

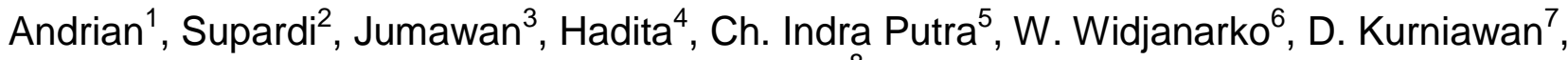 \\ Hafizah $^{8}$
}

${ }^{1-7}$ Program Studi Manajemen, Fakultas Ekonomi dan Bisnis, Universitas Bhayangkara Jakarta Raya

${ }^{8}$ Pendidikan Guru Sekolah Dasar, Fakultas IImu Pendidikan, Universitas Bhayangkara Jakarta Raya

E-mail: zeyvakiraniazahra05@gmail.com ${ }^{1}$, supardi.tahir@gmail.com ${ }^{2}$, jumawan@ubharajaya.ac.id ${ }^{3}$, hadita@dsn.ubharajaya.ac.id ${ }^{4}$, indrahatibie@gmail.com ${ }^{5}$, wwidjanarko2@gmail.com ${ }^{6}$, dody.k2010@gmail.com7, hafizah@dsn.ubharajaya.ac.id ${ }^{8}$

Penulis untuk Korespondensi/E-mail: supardi.tahir@gmail.com

\begin{abstract}
Abstrak
Masa pandemi covid-19 yang masih terjadi di wilayah Kota Bekasi berdampak pada kegiatan pembelajaran kepada para siswa melalui daring yang dilakukan dari kediaman siswa masing masing dengan jadwal yang terbatas, sehingga para guru dituntut untuk inovatif dalam memberikan pembelajaran daring serta kreatif dalam mengisi waktu setelah proses pembelajaran. Kegiatan ini dilakukan untuk memberikan peningkatan kemampuan dan pemahaman para guru di SD Cendrawasih Jaya Kota Bekasi terkait kewirausahaan dan model pembelajaran daring. Para Guru dapat mencari alternatif dalam model pembelajaran daring serta dapat mengisi waktunya untuk memulai berwirausaha secara mandiri, sehingga proses pembelajaran daring menjadi tidak membosankan serta pemanfaatan waktu setelah kegiatan pembelajaran daring agar lebih produktif. Metode pelaksanaan kegiatan ini adalah cara ceramah dan diskusi yang dilaksanakan secara luring. Materi yang diberikan meliputi penjelasan dan pembahasan tentang konsep kewirausahaan, bagaimana memulai wirausaha mandiri, motivasi terkait kegiatan pengajaran kepada para siswa oleh guru serta pemberian contoh - contoh model pengajaran secara daring.
\end{abstract}

Kata Kunci : Kewirausahaan, Motivasi Pembelajaran Siswa, Pembelajaran Daring.

\begin{abstract}
The still occurring covid-19 pandemic in the city area of Bekasi has affected learning activities for students via online living rooms with a limited schedule, so requiring teachers to be innovative in providing online and creative learning time after the learning process. This activity is undertaken to provide increased ability and understanding for teachers at the elementary school of cendrawasih the city of Bekasi with entrepreneurship and online learning models. Teachers can look for alternatives in the online learning model and can fill time to start self-entrepreneurs so that the online learning process is less boring and the time after online learning activities to be more productive. This method of carrying out the activity is the direct delivery of talks and discussions. Materials provided include explanations and discussions about the concept of entrepreneurship, how to start self-entrepreneurs, motivations related to teaching activities by teachers, and example examples of online teaching models.
\end{abstract}

Keywords : entrepreneurship, student learning motivation, online learning. 


\section{PENDAHULUAN}

Masa pandemi COVID-19 yang telah berlangsung sejak awal Maret 2020 sampai saat ini menyebabkan berbagai macam problematika yang harus dihadapi semua sektor kehidupan. Aturan - aturan pembatasan kegiatan telah ditetapkan oleh otoritas pengambil keputusan dan semua sektor kehidupan masyarakat harus mematuhi dan menjalankannya, demi mencegah penularan dan dampak yang lebih besar dari virus ini. Problematika yang dialami oleh berbagai sektor itu perlu disikapi dengan arif dan bijaksana supaya sisi aturan pembatasan dapat dijalankan dan sektor kehidupan masyarakat juga harus tetap berjalan. Dunia pendidikan sebagai salah salah satu sektor penting dalam kehidupan masyarakat yang ikut terdampak harus mencari alternatif pembelajaran kepada para siswa dan siswinya. Salah satu alternatif pembelajaran yang dapat dilakukan adalah model pembelajaran daring atau online. Pembelajaran daring atau online merupakan pembelajaran yang mampu mpeertemukan guru dengan siswa melalui perangkat lunak serta jaringan (Bersin, 2004). Pembelajaran daring menjadi model pembelajaran wajib bagi para sekolah baik dari tingkat sekolah dasar sampai perguruan tinggi, karena pembatasan berkumpulnya banyak orang yang ditetapkan oleh pemerintah dan kegiatan belajar mengajar harus tetap berjalan.

Penelitian yang dilakukan oleh Simatupang et al., (2020) pada beberapa sekolah dasar di DKI Jakarta menyimpulkan bahwa $58 \%$ orang tua siap mengikuti arahan pemerintah dan siap mengikuti pembelajaran secara daring, $42 \%$ orang tua merasa senang menggunakan pembelejaran daring, $21 \%$ reponden mendukung kegiatan pembelajaran daring, hanya $24 \%$ orang tua merasa yakin pembelajaran daring dapat mendorong hasil belajar siswa di sekolah. Pembelajaran melalui e-learnimg atau pembelajaran daring dapat membantu siswa lebih memahami dan menguasai materi matematika yang dijelaskan oleh guru (Utami \& Cahyono, 2020). Keutungan pembelajaran online banyak dirasakan oleh siswa seperti dapat belajar dari rumah, tidak dibatasi waktu dan tempat, dapat mendengarkan kapan saja, tetapi kelemahannya adalah karena ketidakstabilan jaringan sehingga kadang terputus dan ketinggalan materi yang dijelaskan oleh guru (Handayani, 2020). Penelitian lain menyimpulkan bahwa pembelajaran daring menjadi kendala bagi orang tua di rumah karena minimnya pengetahuan teknologi dan adanya pengeluaran untuk mendukung kegiatan pembelajaran lain yang cukup besar (Mastura \& Santaria, 2020). Pandangan dari para orang tua, siswa dan guru yang belum sama terkait manfaat pembelajaran online atau daring mengharuskan pihak sekolah terutama para guru untuk lebih kreatif mencari model model pembelajaran online supaya tujuan pembelajaran dapat dicapai. Kreativitas para guru dalam mencari model pembelajaran yang lebih menarik untuk para siswa akan menumbuhkan rasa bahagia dari dari para siswa dan juga orang tua dan pihak sekolah tentunya. Rasa kebahagiaan yang dirasakan itu dapat memperlancar datangnya rezeki bagi para guru, karena sumber rezeki manusia ada pada kemuliaan dan kebahagiaan orang lain (Nasrullah, 2020).

Pembelajaran daring dapat dilakukan di rumah masing - masing baik siswa maupun guru, pembelajaran daring melalui media online seperti zoom meeting dan google meet dengan waktu yang terbatas. Keterbatasan waktu disebabkan karena kuota jaringan yang terbatas serta kejenuhan yang dialami oleh siswa (Handayani, 2020). Kondisi ini menimbulkan banyaknya waktu yang dimiliki oleh para guru karena biasanya seharian berada di sekolah saat pembelajaran normal. Waktu luang yang ada perlu diisi dengan hal hal yang positif seperti berwirusaha mandiri secara online ataupun offline. Wirausaha merupakan keberanian seseorang untuk melakukan usaha (Sari et al., 2020). Kewirausahaan adalah sebuah kemampuan kreatif dan innovativ yang menjadi kiat dasar dan sumber daya dan proses perjuangan untuk menciptakan nilai tambah terhadap barang atau jasa yang dilakukan dengan keberanian dalam menghadapi segala risiko (Kurniullah et al., 2021). Banyak pelaku wirausaha yang kurang berhasil bahkan mengalami kegagalan dalam menjalankan usahanya, salah satu faktor penyebab kegagalan dalam menjalankan usaha adalah karena modal yang kurang (Srihadiastuti, 2018). Penelitian yang dilakukan oleh Sanny, (2016) menyimpulkan bahwa faktor yang 
menyebabkan kegagalan dalam berwirausaha khususnya waralaba adalah kurangnya komunikasi terintegrasi dengan pemilik awal waralaba, kurang mempunyai keunggulan kompetitif pada produk yang dijual, serta belum adanya pedoman bisnis yang lengkap.

Berdasarkan hasil diskusi dengan Kepala Sekolah SD Cendrawasih Jaya Kota Bekasi (Ibu Hj. E. Aisyah, S.Ag., M.Pdi), bahwa di sekolah yang sedang dipimpin memerlukan terobosan - terobosan dalam proses kegiatan belajar mengajar yang dilakukan secara daring karena masih dalam masa pandemi Covid-19, para guru perlu diberikan motivasi untuk selalu mencari laternatif- alternatif baru dalam proses pembelajaran daring kepada para siswa siswinya agar kegiatan belajar lebih menyenangkan serta diperlukan adanya pembelajaran dasar kewirausahaan supaya para guru dapat mengisi waktunya setelah proses pengajaran secara online untuk memulai berwirausaha.

Target yang ingin dicapai melalui kegiatan ini adalah yang pertama, para guru terutama di SD Cendrawasih Jaya Kota Bekasi mampu memahami pentingnya pembelajaran daring bagi para siswa siswinya sehingga termotivasi untuk mencari alternatif - alternatif dalam melakukan pembelajaran daring, serta target kedua adalah para guru dapat memanfaatkan waktu yang dimilikinya setelah proses pengajaran daring untuk mulai memikirkan, merencanakan dan melaksanakan usaha mandiri secara online maupun offline.

Luaran dari kegiatan pengabdian pada masyarakat ini adalah pemahaman terhadap para guru tentang pelaksanaan pembelajaran daring yang menarik bagi para siswa siswinya, sehingga tujuan penyampaian materi para guru dapat diterima oleh siswa serta mampu memberikan rasa senang bagi para siswa siswi SD Cendrawasih Jaya Kota Bekasi, hal ini sebagai salah satu cara untuk membahagiakan orang lain. Luaran selanjutnya adalah para guru memahami dan mulai berpikir untuk menjalankan usaha mandiri yang dapat dilakukan secara online atau offline dengan pengelolaan yang lebih maju sehingga mampu bersaing dengan usaha - usaha lain yang sudah berjalan. Hasil pelatihan pemberian motivasi pengajaran daring dan kewirausahaan kepada para Guru
SD Cendrawasih Jaya Kota Bekasi ini juga dipublikasikan dalam bentuk artikel pada jurnal pengabdian masyarakat skala nasional.

\section{METODE}

Metode pelaksanaan kegiatan pengabdian masyarakat ini berupa pelatihan secara offline atau luring bertempat di Ruang Rapat SD Cendrawasih Jaya Kota Bekasi. Metode pelatihan digunakan adalah dengan ceramah dan diskusi, dengan susunan acaranya adalah:

1. Pembukaan oleh Kepala Sekolah SD Cendrawasih Jaya Kota Bekasi

2. Sambutan Ketua Pelaksana Kegiatan

3. Penyajian Materi Pelatihan Kewirausahaan

4. Penyajian Materi Motivasi Pembelajaran Daring

5. Tanya Jawab atau Diskusi

6. Pentutup dengan Doa Bersama.

Materi yang diberikan terdiri dari Bagaimana Cara Memulai Kewirausahaan serta pemberian motivasi terkait Bagaimana Mencari Model Pembelajaran Daring yang Mampu Membahagiakan para Siswa dan Siswinya, yang terdiri dari :

1. Kewirausahaan: Konsep Berwirausaha, Manfaat Kewirausahaan, Unsur - unsur Kewirausahaan, Penelitian terdahulu tentang Faktor Penyebab Kegagalan Berwirausaha, dan Memulai Wirausaha.

2. Motivasi Pembelajaran Daring: Pengertian pembelajaran daring, Pandangan orang tua siswa terhadap pembelajaran daring, Mencari alternatif Model Pembelajaran Daring, Merawat Terumbu Karang seorang guru,

\section{HASIL DAN PEMBAHASAN}

\subsection{Persiapan Kegiatan}

Persiapan kegiatan pengabdian masyarakat ini diawali dengan kedatangan Bapak Andrian, SE., MM selaku ketua panitia ke pihak SD Cendrawasih Jaya untuk menemui Ibu Kepala Sekolah sekaligus meminta ijin untuk melaksanakan kegiatan pengabdian masyarakat. Persiapan selanjutnya adalah pembagian tugas untuk 
masing - masing panitia kegiatan pengabdian masyarakat seperti penentuan materi yang akan disampaikan, pemateri yang akan menyampaikan dan persiapan bagian keadministrasian.

\subsection{Pelaksanaan Kegiatan}

Kegiatan ini dilaksanakan pada hari Sabtu, tanggal 17 April 2021, dimulai pukul 09.00 - 12.00 WIB, bertempat di SD Cendrawasih Jaya Kelurahan Duren Jaya, Kecamatan Bekasi Timur Kota Bekasi dengan peserta berjumlah 26 orang guru. Kegiatan pengabdian masyarakat ini berupa pelatihan yang dilakukan secara luring atau tatap muka. Tim pengabdian Masyarakat dari Universitas Bhayangkara yang hadir berjumlah 6 orang dosen yaitu 4 dosen dari program studi manajemen, 1 dosen dari program studi akuntansi dan 1 orang dosen dari program studi Pendidikan guru sekolah dasar.

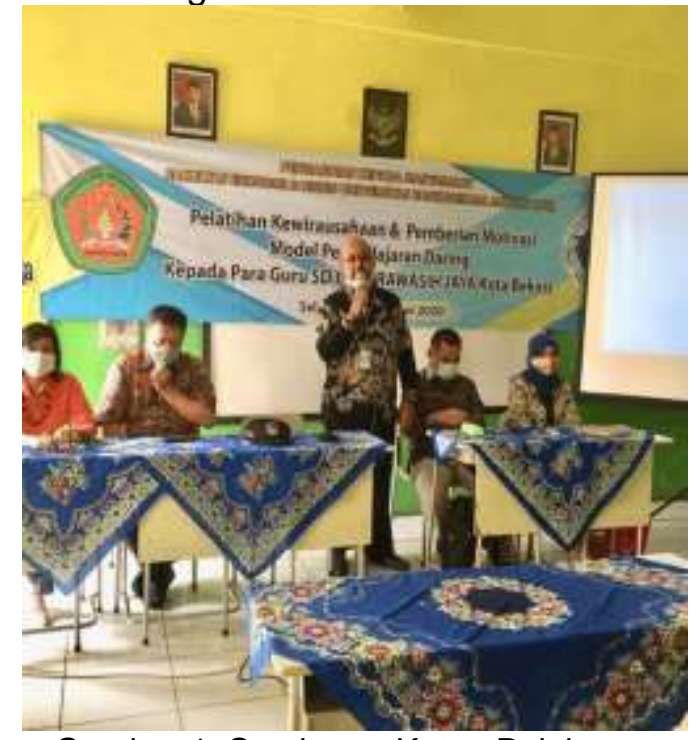

Gambar 1. Sambutan Ketua Pelaksana Sumber: Data Abdimas, 2021

\subsection{Pemaparan Materi Pelatihan}

Materi yang disampaikan pada
kegiatan ini adalah dasar
kewirausahaan dan motivasi pembelajaran daring. Materi dasar - dasar kewirausahaan disampaikan oleh Bapak Wirawan Widjanarko, SE., Ak., MM selaku dosen tetap program studi akuntasi, sedangkan untuk materi motivasi pembelajaran daring disampaikan oleh Bapak Supardi, ST., MM selaku dosen tetap program studi manajemen Universitas Bhayangkara Jakarta Raya.

Para guru SD Cendarwasih Jaya sebagai peserta pada kegiatan ini cukup antusias dalam mengikuti platihan ini, mereka menyadari pentingnya mulai berwirausaha mandiri serta pentingnya mencari alternatif alterntaif model pembelajaran daring dalam kegiatan belajar mengajar selama masa pandemic covid-19.

Peserta pelatihan mendapatkan penjelasan terkait bagaimana cara dan memulai usaha mandiri sambil menjalankan tugasnya sebagai seorang guru, kemudian peserta diberikan motivasi terkait alasan alasan seorang guru harus kreatif dan innovativ dalam mencari model - model pembelajaran daring supaya para siswa siswinya merasa senang dan tidak bosan.

Setelah pemaparan materi selesai disampaikan oleh para narasumber, acara selanjutnya adalah tanya jawab atau diskusi. Para peserta pelatihan yang semuanya adalah para guru SD Cendrawasih Jaya Kota Bekasi mengajukan beberapa pertanyaan baik menyangkut kewirausahaan dan motivasi model pembelajaran daring untuk para siswa siswinya. Beberapa penanya meminta kepada nara sumber untuk memberikan kiat - kiat yang jitu dalam berwirausaha serta menanyakan terkait model - model pembejalajaran daring.

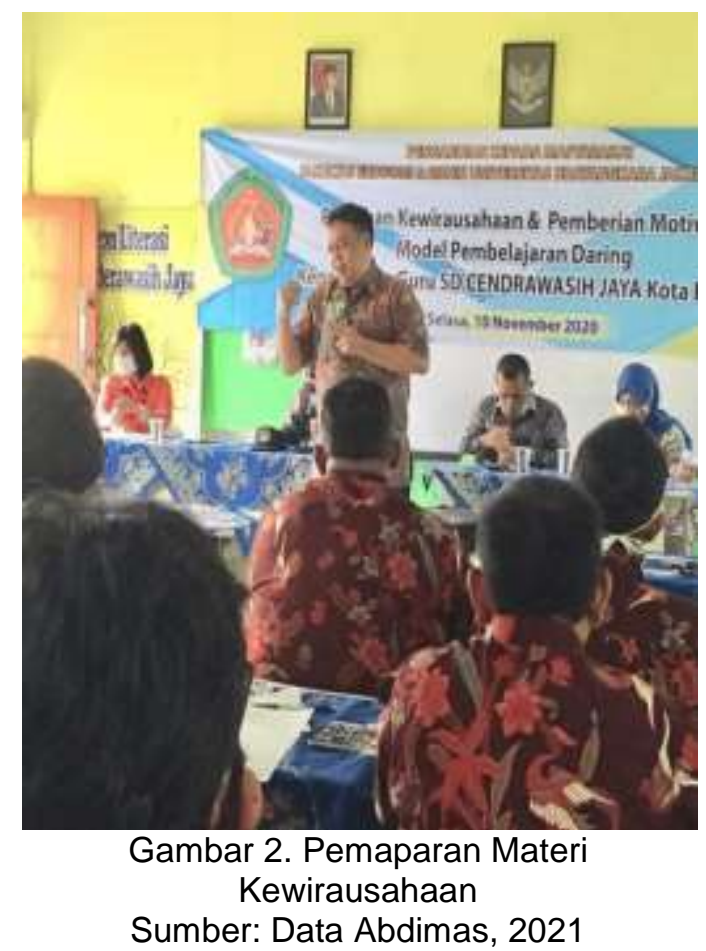




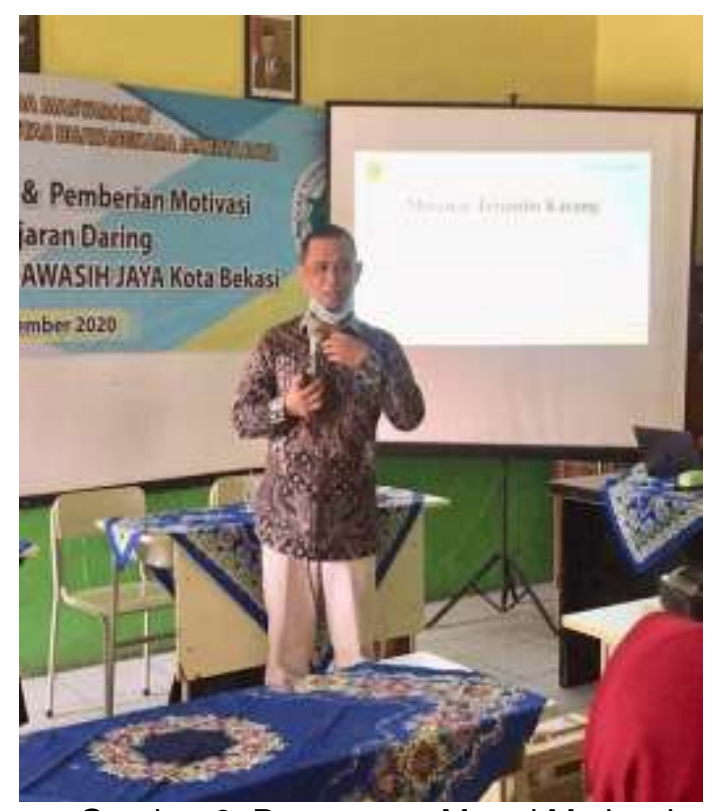

Gambar 3. Pemaparan Materi Motivasi Sumber: Data Abdimas, 2021

\subsection{Indikator Keberhasilan Kegiatan}

Evaluasi dalam kegiatan ini dilakukan dalam dua tahap, yaitu evaluasi awal dan evaluasi akhir. Evaluasi keberhasilan kegiatan ini disesuaikan dengan metode yang dilakukan, dalam kegiatan pengabdian masyarakat ini yang dilakukan dalam bentuk pelatihan dengan metode ceramah dan diskusi atau tanya jawab. Evaluasi yang dilakukan untuk mengetahui tingkat pemahaman para peserta dalam menerima materi yang telah disampaikan oleh para nara sumber. Evaluasi untuk mengetahui tingkat pengetahuan dan pemahaman ini dilakukan dengan memberikan tes kepada peserta yang bentuknya adalah tes pilihan berganda. Sedangkan untuk kegiatan menggunakan metode ceramah, evaluasi dilakukan pada saat peserta membuat draft tentang kewirausahaan, dimana mereka diminta menuliskan usaha apa saja yang akan dilakukan dalam waktu dekat atau setelah pelatihan. Penilaian terhadap peserta diberikan dalam bentuk angka dan dibagi atas empat kategori sebagaimana tabel di bawah ini:
Tabel 1. Kriteria Penilaian

\begin{tabular}{|l|l|}
\hline \multicolumn{1}{|c|}{ Nilai } & \multicolumn{1}{c|}{ Kategori } \\
\hline $81-90$ & Sangat memuaskan \\
\hline $71-80$ & Memuaskan \\
\hline $61-70$ & Cukup memuaskan \\
\hline$<60$ & Kurang \\
\hline \multicolumn{2}{|c|}{ Sumber : Data Abdimas, 2021}
\end{tabular}

Dari 26 peserta yang ikut serta setelah dilakukan evaluasi hasilnya adalah 15 peserta atau $57 \%$ mendapatkan nilai memuaskan, 11 peserta atau $42 \%$ mendapatkan nilai cukup memuaskan.

\section{KESIMPULAN}

Pada saat pandemi covid-19 sekarang ini, banyak sekali sektor perekonomian dan bahkan pendidikan yang terkena dampaknya, dimana para guru apalagi guru honorer di sekolah-sekolah yang banyak kehilangan jam mengajarnya karena berkurangnya siswasiswa di sekolah tersebut, terutama sekolah swasta. Untuk mendapatkan kembali penghasilannya disamping mengajar, mereka dapat memperolehnya dari melakukan wirausaha. Untuk itu perlu adanya penambahan pelatihan-pelatihan kewirausahaan bagi mereka untuk mendapatkan ketrampilan bagaimana melakukan wirausaha yang baik dengan modal kecil dan mendapatkan keuntungan yang optimal sehingga dapat meningkatkan kesejahteraan mereka kembali selama masa pandemi covid -19 yang belum tahu kapan berakhirnya ini. Disamping itu pula perlu diberikan motivasi dalam melakukan proses pembelajaran daring (online) selama masa pandemi ini demi menumbuhkan minat dan motivasi belajar para siswa selama belajar secara daring dari rumah, agar tujuan pendidikan nasional tetap dapat tercapai dengan baik, dan para guru juga dalam melaksanakan proses belajar mengajar dapat mencapai tujuan dan target yang diharapkan.

\section{Ucapan Terimakasih}

Secara khusus rasa terimakasih tersebut kami sampaikan kepada: 1.) Irjen. Pol. (Purn) Dr. Drs. H. Bambang Karsono, S.H., M.M. Selaku Rektor Universitas Bhayangkara Jakarta Raya yang telah memberikan arahan dan semangat bagi para Dosen untuk terus melakukan Penelitian dan 
Pengabdian kepada Masyarakat demi kemajuan di Universitas Bhayangkara Jakarta Raya; 2.) Dr. Istianingsih, M.S.Ak., CA., CSRS., CSRA., CMA., CBV. selaku Dekan Fakultas Ekonomi Universitas Bhayangkara Jakarta Raya, yang telah menyetujui untuk melakukan Pengabdian kepada masyarakat; 3.) Ir. Djuni Thamrin, M.Sc., Ph.D. selaku Kepala Lembaga Penelitian, Pengabdian Masyarakat dan Publikasi yang telah banyak memberikan arahan serta masukan dalam penyempurnaan Laporan Hasil Pengabdian Kepada Masyarakat; 4.) Prasojo, S.Sos., M.Si. selaku Kepala Bidang Pengabdian Kepada Masyarakat dan Kewirausahaan yang telah memberikan arahan serta masukan dalam penyempurnaan Proposal Pengabdian Kepada Masyarakat; 5.) Tri Yulaeli, S.Pd., M.Ak., Akt. selaku Kepala Bagian Keuangan, Universitas Bhayangkara Jakarta Raya; 6.) Rekan-rekan Dosen yang telah memberikan masukan dan pencerahan dalam melakukan penelitian, yang tidak bisa saya sebutkan satu-satu.

\section{DAFTAR PUSTAKA}

Bersin, J. (2004). The Blended Learning Book: Best Practices, Proven Methodologies, and Lessons Learned (CA:Pfeiffer (ed.)).

Handayani, L. (2020). Keuntungan, Kendala dan Solusi Pembelajaran Online Selama Pandemi Covid-19: Studi Ekploratif di SMPN 3 Bae Kudus. JOURNALINDUSTRIAL ENGINEERING\& MANAGEMENT RESEARCH( JIEMAR), 1(2), 15-23. https://doi.org/DOI : https://doi.org/10.7777/jiemar.v1i2

Kurniullah, A., Simarmata, H., Sari, S. ., Sisca, Mardia, Lie, D., \& Anggusti, M. (2021). Kewirausahaan dan Bisnis. Yayasan Kita Menulis.

Mastura, \& Santaria, R. (2020). Dampak Pandemi Covid-19 terhadap Proses Pengajaran bagi Guru dan Siswa. Jurnal Studi Guru Dan Pembelajaran, 3(2), 289-295. https://doi.org/https://doi.org/10.30605/jsgp.3.2.2020.293

Nasrullah. (2020). Rahasia Magnet Rezeki. PT. Elex Media Komputindo.

Sanny. (2016). Analisis Faktor Penyebab Kegagalan Kerjasama dalam Bisnis Waralaba. Jurnal Ekonomi, 7(2).

Sari, A. P., Anggraini, D. ., Sari, N., Gandasari, D., \& Siagian, V. (2020). Kewirausahaan Bisnis Online. Yayasan Kita Menulis.

Simatupang, N. ., Sitohang, S. R. ., Situmorang, A. ., \& Simatupang, I. . (2020). Efektivitas Pelaksanaan Pengajaran Online Pada Masa Pandemi Covid-19 Dengan Metode Survey Sederhana. Jurnal Dinamika Pendidikan, 13(2), 197-203. https://doi.org/DOI 10.33541/jdp.v13i2.1754

Srihadiastuti. (2018). Analisis Peyebab Kegagalan Mendirikan Usaha Baru pada para Lulusan Program Wirausaha Baru Jawa Barat. Jurnal Ekonomi Pendidikan Dan Kewirausahaan, 6(1), 31-44.

Utami, Y. ., \& Cahyono, D. A. . (2020). Study at Home: Analisis Kesulitan Belajar Matematika Pada Proses Pembelajaran Daring. Jurnal IImiah Matematika Realistik (Jl-MR), 1(1), 20-26. https://doi.org/https://doi.org/10.33365/ji-mr.v1i1.252 